\title{
Gondolatok az Európai Kardiológusok Társaságának 2019. évi krónikus koronária- szindróma-ajánlásáról
}

\author{
Ahres Abdelkrim, Andrássy Péter \\ Bajcsy-Zsilinszky Kórház és Rendelőintézet, Kardiológiai Osztály, Budapest \\ Levelezési cím: Dr. Andrássy Péter, Bajcsy-Zsilinszky Kórház és Rendelőintézet-Kardiológiai Osztály, \\ 1106 Budapest, Maglódi út 89-91. E-mail: andrassy.peter@bajcsy.hu
}

\begin{abstract}
A 2019-ben megjelent krónikus koronáriaszindróma (CCS - Chronic Coronary Syndrome) guideline (1) számos helyen különbözik 2013-as (2) elödjétöl és szemléletében is több jelentős változás történt.

A következőkben a teljesség igénye nélkül, néhány véleményünk szerint - súlyponti üzenetet szeretnénk kiemelni. Írásunk során nem térünk ki a kezeléssel kapcsolatos változásokra. Szerzői véleményünk nem tekinthető a Magyar Kardiológusok Társasága, vagy a Cardiologia Hungarica szerkesztősége állásfoglalásának.
\end{abstract}

\section{Változás a terminológiában}

Az eddigiektől jelentősen eltérően Krónikus Koronária Szindrómáról beszélnek stabil angina pectoris helyett. A CCS tulajdonképpen a koronáriabetegség (CAD coronary artery disease) egyik manifesztációja, a másik az akut koronáriaszindróma (ACS - acute coronary syndrome). A CAD egy olyan patológiai folyamat következménye, amely lehet obstruktív vagy non-obstruktív és lefolyása során jelentkezhet CCS vagy ACS tüneteivel, ezeket a hosszú távú kórlefolyás során akár váltogatva is. A jelenleg tárgyalt guideline ugyan a CCS-sel foglalkozik, nagyon helyesen jelentős pontként említik a szerzők az iniciális vizsgálat során a CCS és ACS elkü- lönítését, mivel a két betegség esetében a kórlefolyás, a kivizsgálás és a kezelés is alapvetöen különböznek. A CCS különböző klinikai formákban jelentkezhet, melyeket a jelenlegi guideline hat csoportba sorol (ez az egyik legjelentősebb újítás a korábbiakhoz képest).

1. Stabil angina és/vagy dyspnoe.

2. Új keletű szívelégtelenség, vagy balkamra-diszfunkció hátterében feltételezett koronáriabetegség.

3. ACS vagy revaszkularizáció után egy éven belül tünetes, vagy tünetmenes betegek csoportja.

4. A kezdeti diagnózistól, illetve revaszkularizációtól számított egy éven túli állapot.

5. Angina, ahol vazospazmus vagy mikrovaszkuláris etiológia feltételezhető.

6. Aszimptómás, szűréssel diagnosztizált koronáriabetegség.

A klasszikus diagnosztikus algoritmus az 1-es és a 2-es csoportok esetében van leginkább részletezve. A 3-as és 4-es csoportok között elsősorban a trombocitaaggregáció-gátló kezeléssel kapcsolatban vannak különbségek. Ugyanitt részletezi az ajánlás az utánkövetés módjára és gyakoriságára vonatkozó elveket, amely a korábbiakban kevésbé egyértelmüen volt megadva. Véleményünk szerint ez az újitás segítheti a betegek utánkövetésének homogénebbé, átláthatóbbá tételét. A 6-os entitás külön csoportba sorolását azért tartjuk kiemelten fontosnak, mert a tünetmentes koronáriabe- 
tegség ugyan egy létező formája az ateroszklerózisnak, viszont ezt értelemszerüen csak szürővizsgálatokkal lehet diagnosztizálni. Igen nehéz kérdés viszont, hogy kik azok a betegek, akiket egyáltalán szürni kell és mik azok a vizsgálatok, amiket érdemes elvégezni ezen betegcsoportban. Az ismert SCORE-táblázat (3) alkalmazásán és a családi anamnézis felvételén kívül egyéb vizsgálatok nem szerepelnek I-es osztályú ajánlással a rizikóbecslés során. A magas rizikójú, diabéteszes, pozitív családi anamnézisü betegeknél jön csak szóba a koronária-CT-angiográfia (CCTA), vagy egyéb funkcionális vizsgálat szürés céljából II/B osztályú ajánlással, gyenge (C) evidenciákkal. Alacsony rizikójú, nem diabéteszes betegek szűrővizsgálata bármilyen funkcionális vizsgálattal, vagy CCTA-val (esetleg a hazánkban elterjedt "menedzserszűrés” részjelenségeként fordul elő ez zömében terheléses EKG formájában) szakmailag kontraindikált.

\section{Diagnosztikus algoritmus}

A mellkasi fájdalom, effort dyspnoe kivizsgálására jelentkező, jó balkamra-funkcióval rendelkező betegcsoport (a fentiek szerinti 1-es csoport) kivizsgálási algoritmusában történtek változások. Ez a kardiológiai szakrendeléseken előforduló leggyakoribb CCS forma. $\mathrm{Az}$ anamnézisfelvétel és rutinvizsgálatok (laboratórium, EKG, nyugalmi echokardiográfia, mellkasröntgen) elvégzése után meg tudjuk határozni a CAD „klinikai valószínűségét". Ehhez meghatározhatjuk egyik oldalról a már korábban is alkalmazott PreTest Probabilitást (PTP), másfelöl figyelembe kell vennünk a CAD klinikai valószínűség meghatározóit.

PTP (ESC CCS 2019 guideline 5. táblázata) A PTP jelenleg is a már korábban is ismert módon a mellkasi fájdalom jellege (típusos, atípusos, nem anginás), a beteg életkora és neme alapján meghatározott obstruktív $C A D$ valószínűségét jelenti. A jelenlegi táblázat azonban lényegesen eltér a 2013-ban publikálttól (4), ennek részleteiben való megvitatása azonban jelentősen túlmutat ezen írás keretein. A jelenleg alkalmazott PTP-táblázatban lényegesen alacsonyabb PTP-értékeket találunk (5). Jelen ajánlás szerint $5 \%$ alatti PTP esetében nem kell a betegeket tovább vizsgálni, 5-15\% között megfontolandó, $15 \%$ felett pedig ajánlott további vizsgálatok elvégzése. Ellentétben a 2013-as ajánlással, jelenleg nincs olyan PTP-érték, amely felett azonnal invazív kivizsgálás (koronarográfia) lenne javasolt. Az invazív koronária-angiográfia (ICA - invasive coronary angiography) iniciális vizsgálómódszerként csupán azoknál a betegeknél jön szóba, akiknél:

1. magas a $C A D$ klinikai valószínűsége és súlyos tüneteik vannak megfelelő gyógyszeres kezelés ellenére;

2. alacsony terhelési szinten is típusos angina jelentkezik és a kivizsgálás során (beleértve a terheléses
EKG-t) magas kardiovaszkuláris eseménykockázat mutatható ki;

3. balkamra-diszfunkció, amelynek hátterében CAD feltételezhető.

\section{CAD klinikai valószínúség meghatározói} (ESC CCS 2019 guideline 3. ábrája)

Új elemként jelennek meg a klinikai valószínűség meghatározói, amelyek, mint a PTP további finomítására alkalmas befolyásoló faktorok szerepelnek. Csökkenti a klinikai valószínüséget a normális terheléses EKG és a koronáriákon a kalcium hiánya CCTA-val (Agatston score 0). Növeli a klinikai valószínűséget jelentős rizikófaktorok jelenléte (dyslipidaemia, diabétesz, hipertónia, dohányzás, pozitív családi anamnézis), nyugalmi EKG-eltérések (Q-hullám vagy ST-T-eltérések), balkamra-diszfunkció, amely felveti CAD oki szerepét, abnormális terheléses EKG, kalcium jelenléte a CCTA során. A fentiek figyelembevételével el tudjuk dönteni, hogy magasnak vagy alacsonynak tartjuk a CAD klinikai valószínűségét. Ez nincs számszerüsítve, a klinikus dönti el, hogy az adatok alapján mennyire tartja valószínűnek obstruktív CAD jelenlétét. Ebből a szempontból a jelenlegi guideline több szabadságot ad a klinikusnak a kivizsgálás megtervezésében, szemben a 2013-as ajánlás mechanikusabb algoritmusával.

A CAD diagnózisának kizárása vagy megerősítése az eddig részletezett rizikóbecslést követően több módszerrel történhet.

\section{CCTA}

Elsősorban abban az esetben javasolt, ha alacsonynak tartjuk az obstruktív CAD klinikai valószínüségét, ha jó CT-képminőség valószínű (pl. optimális testalkat, sinusritmus stb.), elérhető a vizsgálat, megfelelő tapasztalat van a vizsgálók birtokában és nincs a beteg anamnézisében korábbi koronáriaesemény. Az alacsony rizikójú betegek kivizsgálásában a CCTA-nak több előnye is van. Nagyon jó a vizsgálat negatív prediktív értéke, szenzitivitása, ezért negatív eredménnyel nagy biztonsággal kizárható az obstruktív CAD jelenléte. A kevésbé súlyos $C A D$ kimutatására (pl. nonszignifikáns koronáriaszükületek) alkalmasabb, mint egy funkcionális noninvazív vizsgálat. Egy 30-40\%-os LAD vagy akár fötörzsszűkület a CCTA-vizsgálat során jól látható, míg egy ilyen anatómiai szituáció esetén egy SPECT vagy egy stressz-echokardiográfia nagy valószínűséggel negatív eredményt fog adni és ezáltal abba a hamis illúzióba ringatja a vizsgálót, hogy a betegnek nincs koszorúér-betegsége. Egy ilyen esetben a pozitív CT-eredmény birtokában a gyógyszeres prevenciós kezelés elkezdésére, illetve annak agresszívabbá tételére nagyobb az esély, mint egy negatív SPECT után.

\section{Noninvazív funkcionális vizsgálatok}

Ezek a vizsgálatok igen magas pontossággal rendelkeznek a flow-t limitáló mértékű CAD detektálására 
és különösen fontosak azon betegek kiválasztásában, akik magas kardiovaszkuláris eseménykockázattal rendelkeznek (a magas kockázatot a jelenlegi guideline - hasonlóan elődjéhez - minden általánosan elérhető tesztre vonatkozóan részletezi). A jelen ajánlás kifejezetten részletesen tárgyalja az új, ún. posztteszt probabilitás témakörét. Ennek lényege, hogy minden noninvazív funkcionális teszt esetében meghatározható az a PTP, ahol az adott módszer a legnagyobb pontossággal alkalmazható arra, hogy az obstruktív CAD jelenlétét megerősítsük (rule-in) vagy kizárjuk (rule-out). Gyakorlatilag egy reklasszifikációs stratégiaként tekinthetünk erre az újonnan bevezetett módszerre, amelyröl egy igen szemléletes ábra is elérhető a guideline-ban (ESC CCS 2019 guideline 5. ábrája), amely korábbi metaanalízis eredményeként született (6). Az ábra külön foglalkozik a leggyakrabban alkalmazott noninvazív vizsgálatokkal és adja meg azok poszt-teszt probabilitásának erősségét mind pozitív, mind pedig negatív prediktív irányban, gold standardként alkalmazva az ICA-t (min. $50 \%$ lumenszükület jelenléte) és az invazív frakcionális flow rezervet (FFR; $\leq 0,80$ ). A noninvazív funkcionális vizsgálatok magasabb rule-in, de alacsonyabb rule-out teljesítőképességgel rendelkeznek, mint a CCTA, kiválasztásukban pedig a betegek jellemzőin (pl. obesitas, pitvarfibrilláció jelenléte, kontrasztanyag- vagy farmakológiai stresszor adásának kontraindikációja stb.) túl szintén az elérhetőséget és a vizsgálók tapasztalatát jelölik meg, de a modalitás megválasztásában kifejezett szabadságot biztosít a klinikus számára. A pozitív noninvazív funkcionális tesztek segítségül szolgálnak a későbbi várhatóan pozitív koronarográfia kiegészítéseként a revaszkularizációs stratégia tervezésében. A CCTA ilyen segítséget nem jelent.

A terheléses EKG alkalmazása, annak gyenge rule-in és rule-out teljesítóképessége miatt összességében önálló modalitásként nem javasolt, csak abban az esetben, ha más modalitás nem elérhető.

\section{Invazív kivizsgálás}

CCS esetében az ICA első vizsgálómódszerként történő alkalmazását a korábbiakban ismertettük. ICA szükséges még diagnosztikus céllal azon feltételezett obstruktív CAD eseteiben, ahol a noninvazív funkcionális teszt eredménye nem egyértelmű (kivételes esetekben még speciális szakmákban dolgozóknál). ICA indokolt lehet azoknál a betegeknél, akiknél a noninvazív teszt magas kardiovaszkuláris eseménykockázatot mutatott ki. Újdonság, hogy minden $50-90 \%$ közötti lumenszükület és többér-betegség esetében kötelező az FFR-mérés elvégzése az ún. határérték-szűkületek funkcionális szignifikanciájának pontos megítélése céljából (hacsak a vizsgált szűkült ér ellátási területére nem rendelkezünk releváns noninvazív iszkémia teszt eredménnyel), különös tekintettel arra, hogy az ilyen súlyosságú lumenszükület mér- téke és azok funkcionális jelentősége között jelentős arányban (30-50\%) mutatható ki mismatch $(7,8)$, ami a betegek reklasszifikációjához és a kezelési stratégia megváltoztatásához vezet.

\section{Következtetések}

Az Európai Kardiológusok Társaságának 2019-es CCS ajánlása sok szempontból elöremutató és a klinikusnak jóval nagyobb szabadságot ad a betegek kivizsgálásában és a döntések meghozásában, azonban a hazai viszonyoknak megfelelően történő alkalmazása és kritikai értékelése elengedhetetlen.

\section{Nyilatkozat}

A szerzők kijelentik, hogy a tanulmány megírásával kapcsolatban nem áll fenn velük szemben pénzügyi vagy egyéb lényeges összeütközés, összeférhetetlenségi ok, amelyek befolyásolhatják a tanulmányban bemutatott eredményeket, az abból levont következtetéseket vagy azok értelmezését.

\section{Irodalom}

1. Knuuti J, Wijns W, Saraste A, Capodanno D, Barbato E, et al. 2019 ESC Guidelines for the diagnosis and management of chronic coronary syndromes. Eur Heart J 2019. doi: 10.1093/eurheartj/ ehz425

2. Montalescot G, Sechtem U, Achenbach S, Andreotti F, Arden C, Budaj A, et al. 2013 ESC guidelines on the management of stable coronary artery disease. Eur Heart J 2013. doi: 10.1093/eurheartj/eht296

3. Conroy RM, Pyörälä K, Fitzgerald AP, Sans S, Menotti A, De Backer $\mathrm{G}$, et al. Estimation of ten-year risk of fatal cardiovascular disease in Europe: The SCORE project. Eur Heart J 2003. doi: 10.1016/S0195-668X(03)00114-3

4. Genders TSS, Steyerberg EW, Alkadhi H, Leschka S, Desbiolles L, Nieman K, et al. A clinical prediction rule for the diagnosis of coronary artery disease: Validation, updating, and extension. Eur Heart J 2011. doi: 10.1093/eurheartj/ehr014

5. Juarez-Orozco LE, Saraste A, Capodanno D, Prescott E, Ballo H, Bax JJ, et al. Impact of a decreasing pre-test probability on the performance of diagnostic tests for coronary artery disease. Eur Heart J Cardiovasc Imaging 2019. doi: 10.1093/ehjci/jez054

6. Knuuti J, Ballo H, Juarez-Orozco LE, Saraste A, Kolh P, Rutjes AWS, et al. The performance of non-invasive tests to rule-in and rule-out significant coronary artery stenosis in patients with stable angina: A meta-analysis focused on post-test disease probability. Eur Heart J 2018. doi: 10.1093/eurheartj/ehy267

7. Van Belle E, Rioufol G, Pouillot C, Cuisset T, Bougrini K, Teiger $E$, et al. Outcome impact of coronary revascularization strategy reclassification with fractional flow reserve at time of diagnostic angiography: Insights from a large french multicenter fractional flow reserve registry. Circulation 2014. doi: 10.1161/CIRCULATIONAHA.113.006646

8. Curzen N, Rana O, Nicholas Z, Golledge P, Zaman A, Oldroyd $\mathrm{K}$, et al. Does routine pressure wire assessment influence management strategy at coronary angiography for diagnosis of chest pain? The ripcord study. Circ Cardiovasc Interv 2014. doi: 10.1161/CIRCINTERVENTIONS.113.000978 